This item was submitted to Loughborough's Research Repository by the author.

Items in Figshare are protected by copyright, with all rights reserved, unless otherwise indicated.

\title{
Commons manifestos: a reply to Bauwens and Ramos
}

PLEASE CITE THE PUBLISHED VERSION

https://doi.org/10.1080/23269995.2018.1461443

PUBLISHER

Taylor and Francis

VERSION

AM (Accepted Manuscript)

PUBLISHER STATEMENT

This is an Accepted Manuscript of an article published by Taylor \& Francis in Global Discourse on 12 July 2018, available online: http://www.tandfonline.com/10.1080/23269995.2018.1461443.

\section{LICENCE}

CC BY-NC-ND 4.0

\section{REPOSITORY RECORD}

Murdock, Graham. 2019. "Commons Manifestos: A Reply to Bauwens and Ramos". figshare. https://hdl.handle.net/2134/32366. 
To appear in Global Discourse: An Interdisciplinary Journal of Current Affairs and Applied Contemporary Thought.

\title{
Commons Manifestos: Resisting Enclosure, Retrieving Mutuality
}

\author{
Graham Murdock
}

\begin{abstract}
This reply piece is a response to the article by Michel Bauwens and Jose Ramos, "Re-imagining the Left through an ecology of the commons: Toward a postcapitalist commons transition". In it, Graham Murdock argues that while developing a commons for contemporary conditions is a core requirement for a post-capitalist social order it Is not in itself sufficient. It is also necessary to confront the contradictory role the state has played in the development of capitalism, as both a force for enclosure and the defence of property rights and the prime guarantor of the public goods and social conditions that facilitate commoning. The rise of neo liberal economic polices has fuelled a new push to enclosure characterized by the privatisation of previously public resources, accelerated corporate concentration, widening income inequalities, and a deepening ecological crisis. The leading digital corporations have played a central role in cementing these processes. Consequently, mobilising digital technologies for commoning requires concerted state action to reverse them and restore the public resources and social conditions that support mutuality.
\end{abstract}

"The future is already here; it's just not evenly distributed" - William Gibson

Every year since 1987, political elites and prominent representatives of global business have attended the World Economic Forum in the Swiss mountain resort of Davos to discuss mounting threats to profits and social stability. These threats include a deepening environmental crisis and the rapidly widening wealth and income inequalities generated by the aggressive pursuit of market fundamentalist policies, a fundamentalism developed and coordinated at the WEC. It is ironic but entirely fitting that a gathering crowded with figures who have minimised their tax liabilities by secreting their gains in offshore tax havens should be meeting in the town where Robert Louis Stevenson finished writing the classic story of hidden wealth, Treasure Island. Every year it becomes clearer that proposals for modest market modifications and technological fixes cannot address the current crisis of globalised capitalism. But it is equally clear that the historic alternatives, of state directed communism and state managed social democracy, are also in crisis, discredited by the Soviet Union's collapse and the failure of the major parties of the Western Left to effectively counter the neo-liberal agenda of privatisation and austerity. This vacuum has been all too readily filled by authoritarian populist movements from the Right rooted in appeals to imagined ethnic and national purities and superiorities.

Surveying this bleak landscape, a growing number of commentators on the Left are looking beyond market-state relations. Animated by the new forms of peer-to-peer 
collaboration supported by digital networks they have returned to the experience of the commons, the third term in the political economy of modernity previously pushed to the margins in dominant discourses. The paper by Michel Bauwens and Jose Ramos in this issue is the latest contribution to a general effort to draft a Commons Manifesto for a post capitalist future. They draw on Germany's recent transition to clean energy to outline a productive but relatively limited role for the state in supporting commons solutions. I want to suggest that rather than minimising the role of the state, the transformational promise of communing can only be secured by retrieving and rethinking it. The state remains both the essential bulwark against the private appropriation and exploitation of the core resources that support communing and the essential guarantor of the conditions that enable it.

A commons is defined by four features. First, it is a cluster of shared common pool resources seen as essential to personal and public well- being. Second, access and use of these resources is managed collectively according to mutually agreed rules and protocols. Third, practices of communing are informed by an ethos of reciprocity and collaboration and a commitment to contribute to the sustainability and quality of collective life. Fourth, this commitment is underpinned by a philosophy of custodianship of core resources diametrically opposed to their exploitation for personal gain.

The history of the commons is always and everywhere also the history of enclosure. Capitalism is based on the privileges accorded to private property and the legal mandate they confer on the appropriation and exploitation of shared resources. This history is missing from Bauwens and Ramos's account. It is essential to retrieve it because it demonstrates that states have played a central role in enabling communing as well displacing and dismantling it.

The commons of medieval Europe supported a subsistence economy based on access to grazing, foraging for foodstuffs, and gathering fallen wood for heating, building and making tools. It was underwritten by customary rights based on past practices, but as Marx discovered as a young journalist on the Rhineland News reporting on the new law reclassifying wood collection as theft. Within the emerging economic order property rights took precedence (Marx 1975 [1842]). Based later in London he saw the progressive enclosure of common land in England playing a central role in the consolidation of capitalism (Marx 1976 [1867]). It cleared the way for the intensification of agricultural production and fossil fuel and mineral extraction setting in motion an escalating cycle of ecological degradation .By eradicating peasants' means of self-sufficiency and forcing them to seek work in the industrial centres as wage labourers it fuelled demand for a proliferating range of manufactured commodities replacing a moral economy of mutuality with a market centred individualism.

Enclosure was also a central driving force in the colonial expansion that forged a global capitalist order but here dispossession was total. The declaration of Australia as 'empty land' gave British colonists carte blanche to appropriate ancestral aboriginal territory for large scale farming and intensive mining. It was a process repeated with the annexation of native American lands in North America and the seizure of Maori 
lands in New Zealand. The comprehensive appropriations that accompanied this drive for accumulation were reproduced in the cultural sphere. Indigenous practices, knowledges, and languages were supressed and delegitimized. The ethos of custodianship was replaced by an ideology of 'progress' that classified natural resources as free gifts available to be exploited indefinitely without penalty.

Reorganising knowledge in the heartlands of capitalism proved less straightforward. Bauwens and Ramos present medieval monasteries as hubs in acknowledge commons with "uncanny" resemblances to digital networks. Monasteries certainly played a central role in curating, developing and distributing knowledge resources but their practices relied on Latin, the international lingua franca of the learned, as both a spoken and written language. This supported a borderless network of circulation but confined access to a privileged stratum of educated aristocrats and clerics. The rise of printing and translation into vernacular languages dismantled this monopoly. Efforts to retain control over the circulation of knowledge shifted to struggles over state licensing and intellectual property law with the state again acting as an agency for enclosure. At the same time it also acted as a democratising force.

The formation of an urban proletariat opened new fronts in the struggle over access and use of core resources. Emerging local and occupational communities and social movements organised multiple forms of self-directed collective support and action with the co-operative and not for profit organisations developed by socialist groups playing a central role in forging new practices of communing outside the commodity system. Mounting popular demands for access to the material and cultural supports for effective agency and collective well-being, fuelled by the new ideal of universal citizenship, successfully secured a series of governmental interventions that limited commercial enclosure and delivered core cultural and communications resources as public goods, paid for collectively out of taxation. .There were libraries, museums, parks, adult educational institutions and public post and telephone networks providing connectivity. State intervention also laid the basis for the mass literacy that opened the possibility of generalised access to the knowledge and skills that supported collective agency.

The self-organisation of grass roots urban communing clashed continually with the paternalism, bureaucratisation and impetus to control animating the top-down administration of public goods, but it was state intervention that placed limits on commercial enclosure and ensured access to the spaces and resources which enabled communing. A democratic knowledge commons would not have thrived without the public library system and the universal right to education.

The assertive return to market fundamentalism since the late 1970s has decimated and dismembered this essential underpinning of public provision. Core public assets have been sold to private entrepreneurs and restraints on corporate accumulation relaxed, ushering in a new and intensified enclosure. The leading internet companies have been major beneficiaries of this marketizing push. Effective control over the core digital technologies that organise popular access and use in the capitalist West is currently vested in five US based companies-Alphabet, Amazon, Apple, Facebook and Microsoft- all now listed among the top ten global corporations and directed by men among the world's richest. Their control is currently being extended by their leading 
role in developing the next generation of digital technologies built around cloud computing, artificial intelligence, robotics and the internet of things. Their economic and social centrality has major implications for the viability of both the civic and natural commons.

The commercial enclosure of natural resources has also accelerated under neoliberalism with essential energy and water supplies privatised and previously inaccessible areas opened for new mining and drilling for rare minerals and fossil fuels. Digital media are centrally implicated in the ensuring ecological destruction. By providing extended platforms for product promotion they have intensified general levels of wasteful consumption while themselves developing arrays of infrastructures and devices that deplete scare resources in their production, consume increasing volumes of energy and water in their use, and, as presently fabricated, add significantly to pollution waste in their disposal (Brevini and Murdock 2017 ). Digital commoning cannot piggy back on existing technologies. It must develop new, ecologically sustainable, practices across design, production and use

Market fundamentalism has also reversed post war progress toward greater income and wealth equality, opening ever wider divisions of condition and opportunity between those at the top and bottom of the scale ( Picketty 2014 )

None of this was envisaged by early champions of digital technologies who greeted them as unstoppable disruptive and democratising forces that would replace the closed vertical power lines commanded by centralised institutions with horizontal, peer-to-peer, networks of inclusive and self-governing collaborative production and exchange. The persistence of this digital commons, embodied in the open source movement and later co-operative ventures, seems to herald a new post capitalist order. It is enticing vision but it ignores the three key counter forces: the acceleration of corporate concentration, widening income inequalities, and ecological destructive technologies.

The increasingly militant mobilisation of First World Nations has placed them in the front line of recent movements opposing the exploitation of natural resources on ancestral lands. Indigenous communities' historic commitment to collective custodianship has recently been recognised in law with the New Zealand Parliament's landmark decision to accord the Wanganui River, sacred to local peoples, the same legal protections as a person. Alongside these intensifying struggles for sustainable stewardship of natural resources and the mitigation of the climate crisis that will determine the future quality of collective life at a fundamental level, we see escalating opposition to the private appropriation of the core material and cultural resources that organise social relations in the cities, where for the first time in human history, the majority of the planet's population now live.

This account points to two unavoidable conclusions. First, struggles against the commercial enclosure of the digital domain are inextricably bound up with wider struggles against the enclosure of both natural resources and civic life. Extending the economic and social reach of digital communing depends on securing the full range of conditions that support practices that are both ecological sustainable and guarantee 
equality of access and participation. Second, fighting and winning these battles returns us to historic arguments over the role of the state and international agencies in securing social justice and ensuring the effective democratic organisation of collaboration and mutuality. A strategy for commoning that does not eradicate prevailing inequalities in access to core resources and capacities and address the possibly unequal impacts of proposed transformations will leave control of the future in the hands of the already advantaged.

,Recasting the relations between our identities as citizens, commoners, and members of a species that shares the planet's natural resources with myriad other life forms, remains the central challenge facing the future of social relations grounded in mutuality rather than destructive individualism. The eloquent advocacy of commoning advanced by Bauwens and Ramos is necessary but not sufficient. We also need to rethink the philosophy and practices of public goods and state intervention in supporting and securing the resources and capacities that enable self-organised creativity and provisioning.

\section{References}

Brevini, Benedetta and Murdock, Graham (2017) Carbon Capitalism and Communication: Confronting Climate Crisis. London. Palgrave Macmillan.

Marx, Karl 1975 [1842] 'Debates on the Law of Thefts of Wood' in Karl Marx/Frederick Engels Collected Works Volume 1. Maex:1835-1843. London. Lawrence and Wishart.

Marx, Karl 1976 [1867] 'So called Primitive Accumulation' in Karl Marx Capital Volume 1,pp 873-940.

Piketty, Thomas (2014) Capital in the Twenty-First Century. Cambridge. Mass. The Belknap Press of Harvard University Press. 